\title{
Jordan's Water Resources: Increased Demand with Unreliable Supply
}

\author{
Saad Merayyan ${ }^{*}$, Salwa Mrayyan² \\ ${ }^{1}$ Department of Civil Engineering, California State University, Sacramento, USA \\ ${ }^{2}$ AL-Balqa Applied University, Al-Huson, Jordan \\ Email: " merayyan@csus.edu
}

Received 4 February 2014; revised 5 April 2014; accepted 21 April 2014

Copyright (C) 2014 by authors and Scientific Research Publishing Inc.

This work is licensed under the Creative Commons Attribution International License (CC BY). http://creativecommons.org/licenses/by/4.0/

(c) (i) Open Access

\begin{abstract}
Jordan is a small county located in the Middle East. Jordan has borders with Saudi Arabia, Syria, Iraq, and Israel (Figure 1). Jordan was established in 1921 and has very limited natural resources. Jordan's current (2008) population is 6.5 million. The country has a total land area of $750,000 \mathbf{~ k m}^{2}$, about one third $\left(92,300 \mathrm{~km}^{2}\right)$ of which is dry land while the other two thirds $\left(329,000 \mathrm{~km}^{2}\right)$ are irrigated land. Jordan is considered as a water poor country due to unreliable and shortages in the supply of water sector. This makes it very difficult to meet the required and steadily increasing demand. Impact of climate change adds a layer to the uncertainty on the supply side of Jordan's water portfolio. This paper addresses the water supply challenges that Jordan faces and what has been accomplished to improve supply and/or reduce demand. Many projects were undertaken or planned by the Jordanian government to increase the water supply and improve its reliability. Completing the proposed projects will result in Jordan meeting its water demand [1]. otherwise, the Jordanian Government implement some or all the proposed short term solutions as presented in this paper.
\end{abstract}

\section{Keywords}

Water Resources, Middle East, Jordan, Supply, Demand, Reliability

\section{Background}

Jordan's limited water resources supply fluctuates around a stationary [1]. The normal population growth, in addition to the massive influx of refugees from neighboring countries, made the limited water supply in the country even worse. The majority of water resources experts classify countries with less than $1000 \mathrm{~m}^{3}$ per (year-ca-

*Corresponding author.

How to cite this paper: Merayyan, S. and Mrayyan, S. (2014) Jordan's Water Resources: Increased Demand with Unreliable Supply. Computational Water, Energy, and Environmental Engineering, 3, 48-56.

http://dx.doi.org/10.4236/cweee.2014.32007 


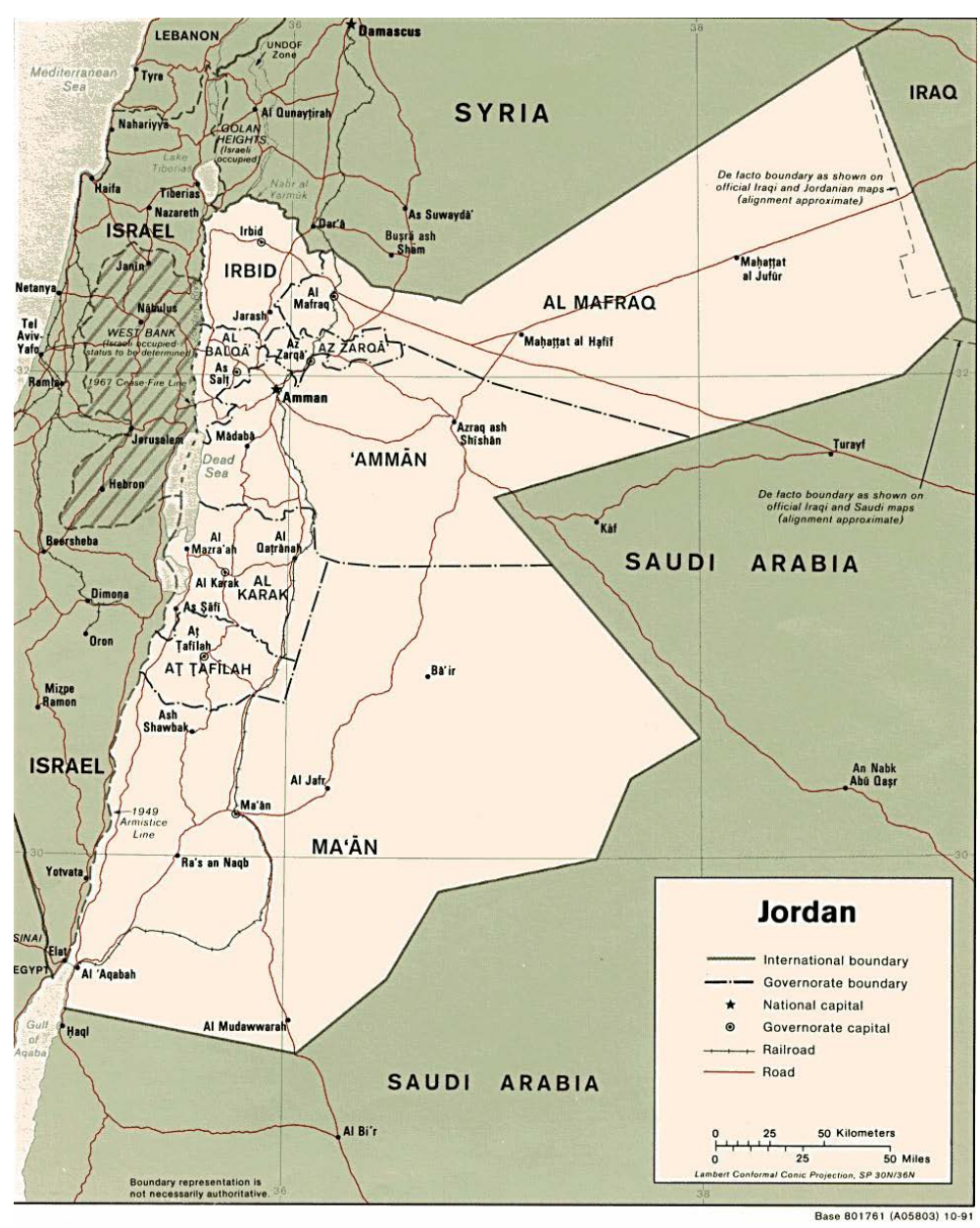

Figure 1. Map of Jordan.

pita) as water poor countries. In 1997, Jordanians consumed only 883 million cubic meters (MCM), which translates to about $200 \mathrm{~m}^{3}$ per (year-capita). The 1997 water consumption rate-when compared to the rates of neighboring countries-was 65\% less than that consumed in Syria and Israel, and 85\% less than that of Egypt [1].

The gap between water supply and demand is expected to increase due to the steady increase in population. If the current population growth trends follow what is projected, in 2025 the annual water consumption per capita will decrease from its 1997 levels of $200 \mathrm{~m}^{3}$ per (year-capita) to $91 \mathrm{~m}^{3}$ per (year-capita) [1].

In 2000, Jordan needed 1258 MCM to meet its domestic, industrial and agriculture demand. Faced with these challenges, the Jordanian government water planners devised a plan to increase the water supply, improve the delivery efficiency and reduce certain sectors demand. The increase of the water supply was partly achieved as an outcome of the peace treaty that was signed between Jordan and Israel in 1994, which ensures an additional 215 MCM of water via the building of additional dams, as well as pipelines on the Yarmouk and Jordan rivers. Other projects that the Jordanian government proposed to improve water supply are purchasing water from other countries (i.e. Turkey) and/or constructing a canal "The Two Seas Canal or the Peace Conduit" to bring water from the Red Sea to the Dead Sea. The proposed Two Seas Canal will be constructed with the participation of Israel and the financial support of the United States and the European Union. The Canal will bring 1.8 billion $\mathrm{m}^{3} /$ yea of sea water which will then be treated using desalination to provide about $850 \mathrm{MCM}$ of portable water to Jordan, Israel and Palestine [1] [2].

The water issue in the Middle East is not only a limited resource. It's also a source of conflict that might require world intervention. Participation in and funding of such projects will, on the long run, provide the people of Jordan with the necessary supply of water, hence improve the overall health and quality of life and, reduce any potential for conflict. 


\section{Jordan's Climate}

Jordan's weather is classified as semi-arid to arid with hot and dry summers, and cold and wet winters. Jordan's precipitation (Figure 2) varies in magnitude, intensity, and distribution. Most of the precipitation in Jordan occurs between the months of October and May of each year [2]. The average annual precipitation in Jordan is 50 200 mm, 100 - 300 mm, and 200 - 600 mm in Jordan’s Desert, Jordan’s Valley, and Highlands, respectively. In a typical wet year, the total precipitation is about $1200 \mathrm{MCM}$ and is half of that in a typical dry year. The evaporation rates in Jordan vary from $63 \%$ from the highlands to $99 \%$ from the desert. The typical long-term evaporation average is $93 \%$.

\section{Surface Water Resources}

The majority water re-charge comes from precipitation, which dramatically varies from year to year [3]. The surface water, base flow, and runoff long-term averages are 713 MCM, 451 MCM, and 256 MCM, respectively. There are three major surfaces water systems in Jordan. These systems are: Jordan River that has a catchment area of $18,194 \mathrm{~km}^{2}$, The Yarmouk River, which has a catchment area of $67,890 \mathrm{~km}^{2}$. About $1160 \mathrm{~km}^{2}$ of the Yarmouk River catchment area is located in Syria. The third major river in Jordan is the Zarqa River. The Zarqa River has a catchment area of $4025 \mathrm{~km}^{2}$ and its water is not shared with any of Jordan's neighboring countries. The Zarqa River catchment area is densely populated, where about 65\% of Jordan's population resides and about $80 \%$ of Jordan's industry located. The effluent form several wastewater treatment facilities (e.g. As-Samra,

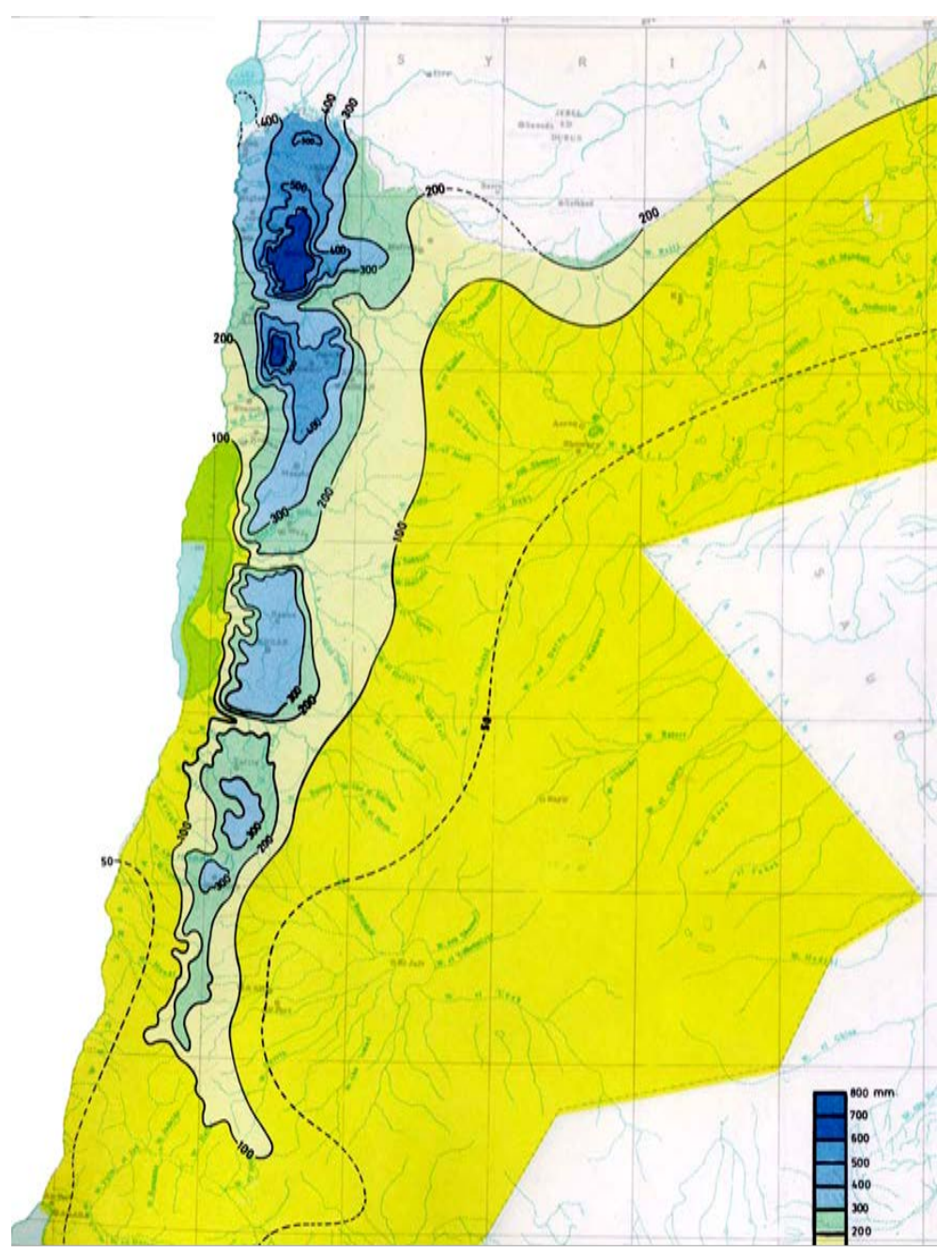

Figure 2. Annual precipitation (M. Mohsen, 2007). 
Jeresh, and Ba'qa WWTP) discharge to the Zarqa River. The Zarqa River is controlled by the King Talal Reservoir and its water is mainly used for agriculture and livestock demands [3]. The percentage of treated sewerage that is discharged into the Zarqa River is $50 \%$ in the winter months and about $60 \%$ in the summer months. There are two surface water bodies in Jordan: The Dead Sea and the Gulf of Aqaba. Figure 3 shows the fifteen surface water basins while Table 1 provides a summary of the annual flow from each basin.

\section{Groundwater Resources}

Groundwater is considered to be the main source of water supply in many regions of Jordan and is the only water supply in other regions. More than half of the water supply in Jordan comes from groundwater basins. There are twelve groundwater basins in Jordan (Figure 4). The Disi and Jafer basins are considered to be "fossil" aquifers. The annual safe yield from these two aquifers is 12 MCM [4]. Recent studies showed that the Disi aquifer can support annual abstraction of 125 MCM for about 50 years [4] [5]. The two largest aquifers that are rechargeable aquifers are the Amman-Zarqa basin and the Dead Sea basin. The maximum annual safe yield from these two basins is 144 MCM. Table 2 provides a summary of the annual safe yield supply from various aquifers in Jordan [6].

\section{Wastewater Resources}

Twenty-six of Jordan's cities are served by nineteen wastewater treatment plants (WWTP) [4]. The Majority of these treatment plants are stressed. The treated wastewater is considered an integral part of Jordan's sustainable water resources system. About $70 \%$ of the population living in urban areas is serviced with sewer collection system. The annual treated wastewater effluent form theses serviced areas is about 80 MCM [1] [3]. The treated effluent is typically used to meet agriculture and livestock demands and as a groundwater recharge source. The agriculture demands are mainly directed towards the Jordan Valley, where the majorly of Jordan's agricultural is located.

The two largest wastewater treatment plants in Jordan are the As-Samra and Irbid (Wadi AL-Arab) WWTP. The design capacity of the As-Samra WWTP is $68,000 \mathrm{~m}^{3} /$ day and Irbid (Wadi Al-Arab) WWTP design capacity is $21,000 \mathrm{~m}^{3} /$ day [1] [2].

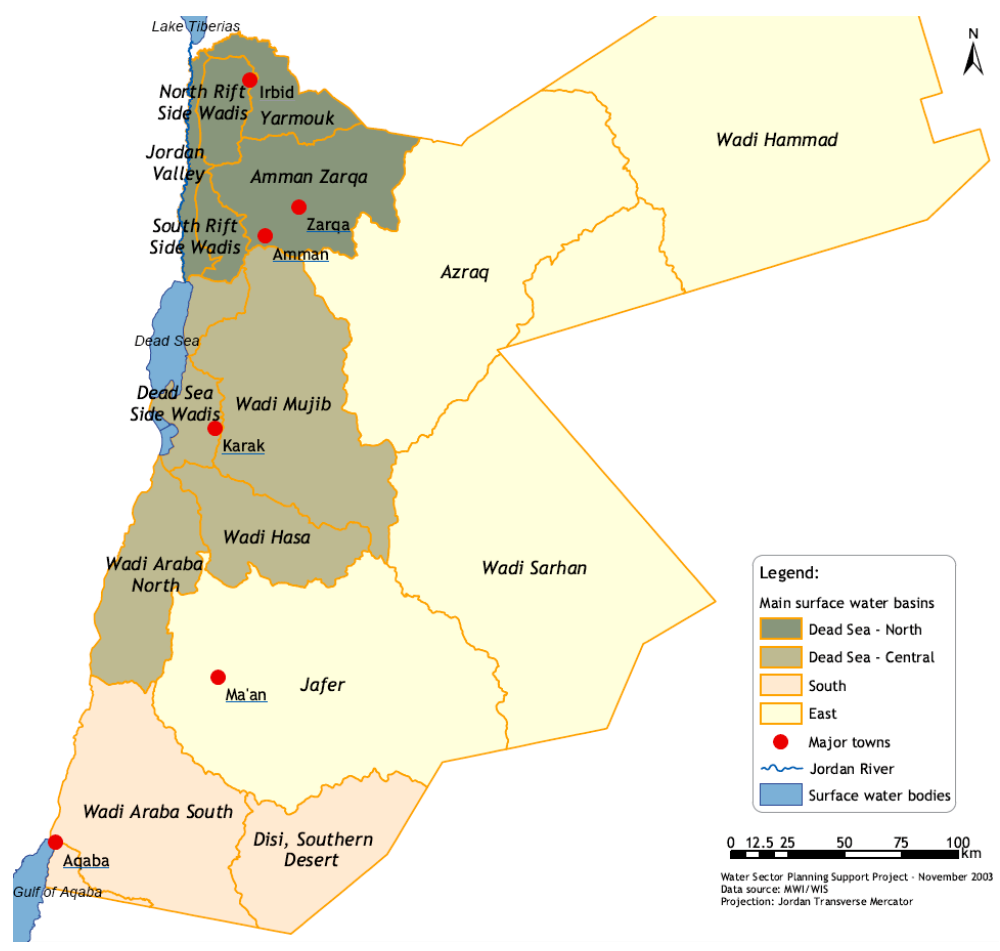

Figure 3. Surface water basins. 
Table 1. Catch basin flow.

\begin{tabular}{cc}
\hline Basin & Annual flow (MCM) \\
Yarmouk & 166 \\
Zarqa & 84 \\
N. Side Wadi & 58 \\
S. Side Wadi & 58 \\
Jordan Valley & 8 \\
Wadi Mujib & 102 \\
Dead Sea Side Wadi & 43 \\
Wadi Hasa & 43 \\
Azraq & 41 \\
Wadi Hammad & 24 \\
Wadi Sarhan & 18 \\
Jafer & 13 \\
Disi, Southern Desert & 43 \\
N. Wadi Araba & 13 \\
S. Wadi Araba & 46 \\
Total & 8 \\
\hline
\end{tabular}

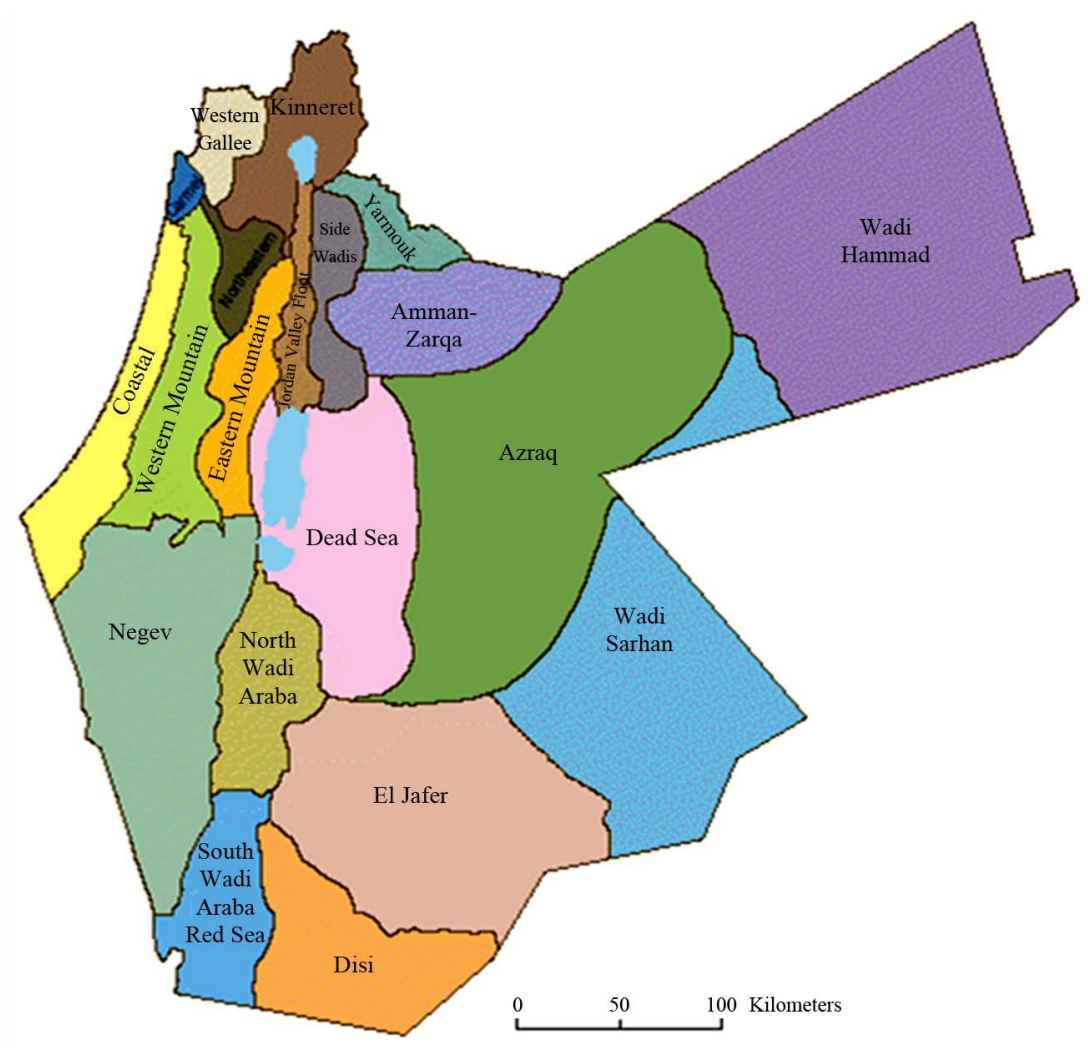

Figure 4. Groundwater basins. 
Table 2. Catch basin flow.

\begin{tabular}{cc}
\hline Basin & Annual flow (MCM) \\
Yarmouk & 166 \\
Zarqa & 84 \\
N. Side Wadi & 58 \\
S. Side Wadi & 58 \\
Jordan Valley & 8 \\
Wadi Mujib & 102 \\
Dead Sea Side Wadi & 43 \\
Wadi Hasa & 43 \\
S. Wadi Araba & 6 \\
Wadi Sarhan & 5 \\
N. Wadi Araba & 5 \\
Disi (Fossil) & 4 \\
\hline
\end{tabular}

Additional sustainable source of water in Jordan is obtained from desalination plants. There are two operating desalination plants in Jordan. They are the Abu Zeghan and Zara plants with a total combined treatment capacity of about 31 MCM (10 MCM from Abu Zeghan and 21 MCM form Zara). The desalinated water from these two plants is added to the overall water supply in Jordan. Desalination treatment plants are typically expensive to build and operate in a country with limited resources like Jordan [2] [4].

\section{Discussion}

There are several challenges facing the water sector in Jordan. These challenges include elevated levels of normal population growth rates (including population migrations due to regional conflict), degrading surface and groundwater qualities, and changes in precipitation patterns due to climate change [3] [4].

The annual average population growth rate is about $2.5 \%$, which is relatively high when compared to other countries of Jordan's size and resources. The massive fluxes of thousands of refugees (in the span of few months at a time) from neighboring countries as a result of several regional conflicts (e.g. the first Gulf War, the continuous Arab-Israeli conflict, and the second Gulf War) caused an alarming and sudden increase on the water demands in Jordan. In addition to the population increase, the living standards in Jordan are steadily improving and as a result the industrial and agricultural demands are increasing.

To make things worse, Jordan's population projections for the year 2020 is about 9.9 million with $65 \%$ of the populations will be served with sewer service. The projected sewerage generation is about 237 MCM, which is about three times the sewerage generation from the current population estimates [4] [7].

In 1999, the domestic water consumption was 231.5 MCM (29\% of the total consumed water in the country). About 79\% of the water supply for domestic uses comes from groundwater sources with the exception of the water that is pumped from the Yarmouk River to meet Amman's water demand. The portable water infrastructure in Jordan is not very efficient. Only $45 \%$ of the daily domestic consumption accounted for and about 55\% of the daily domestic consumption is lost. Table 3 provides a summary of Jordan's water demands and their sources.

The effluent's salinity from WWTP in Jordan is typically higher than normal due to low domestic use levels (due water conservation efforts, and intermittent service) and the use of standard treatment technologies like stabilization ponds in the current WWTP. In addition, to the reasons mentioned above, the high evaporation rate in Jordan results in loss of liquid sewerage water from the stabilization ponds to the atmosphere, which in turn increases the sewerage water salinity. The use of the brackish water to recharge groundwater sources result in additional degradation of the groundwater supply.

The regulation on industrial discharge to the public sewer collection lines is loosely enforced in Jordan. Therefore, industrial effluent from various types of industries with varying industrial wastewater strengths are 
currently being discharged into public sewers collection lines and eventually treated by municipal WWTP using standard technologies that is used to treat domestic sewerage. As result, when released, the treated effluent from the municipal WWTP is less desirable for agricultural purposes.

Industrial demands accounts for about 5\% (Table 3) of Jordan's total water supply [5]. About 94\% of the industrial demand comes from groundwater resources. This is projected to increase due to improvements in the industrial sector in the country, Jordan's inclusion in the World Trade Organization (WTO) and the signed free trade agreements between Jordan and the United States and the establishments of the free zones in different regions of Jordan. These agreements make Jordan a desirable destination for regional investors and manufacturers.

The agriculture sector in Jordan is the largest water consumer. This sector uses about $65 \%$ (see Table 3 ) of the total water supply in Jordan. About $49 \%$ of the agricultural demand comes from groundwater resources. The majority of the irrigated land in Jordan is located in the highland and the desert (about 52,700 hectares), and in the Jordan Valley (about 31,600 hectares).

It's clear the importance of groundwater in Jordan's overall water resources plan to meet its current water demand. Yet there is a shortage of about $40 \%$ in the groundwater supply to reach the current total and required water demand. The 2005 estimates of available water supplies in Jordan from various sources is 816 MCM (275 MCM from Groundwater, 56 MCM groundwater recharge, 395 MCM surface water, 80 MCM from WWTP effluent, and $10 \mathrm{MCM}$ from desalinated water). The projected increase in the water demand form the three major sectors (99\% of the total water demand) in Jordan are presented in Table 4.

A quick comparison of the water supply in 2005 (used as a reference for the comparison) with water demand in 1999, 2005, 2010 and 2020 (see Table 5) reveals major water deficit in all years analyzed expect in 1999. It's clearly demonstrated that the problem of water shortages in Jordan is a chronic problem for years to come. If the current domestic, agricultural and industrial practices are not addressed, the water supply in Jordan will deplete in quantity and quality with time. This will also make the problem of water shortages even worse than actually shown in Table 5. Overdraft of groundwater and surface water is creating a tremendous stress on the water supply in Jordan. Large losses from surface waters (i.e. the Dead Sea) are also a problem that the Jordan has to address in order to at least to reduce these losses.

In order for Jordan to balance its water budget, support the growth plans envisioned in the country, and provide the basic element of life to Jordanians, the government needs to take certain steps to increase the water supply and reduce demands.

Increasing supply should be the most important objective of Jordan's water planners. In order to achieve this objective, the government is forging ahead with major joint projects with neighboring countries (Egypt, Syria, Israel, and Palestine) and applying water conservation practices. The steps that the government is proposing to meet and exceed the water demand are listed below.

Table 3. Water demand in MCM by sector in 1999.

\begin{tabular}{ccccccc}
\hline Use & $\begin{array}{c}\text { Groundwater } \\
\text { Sources (GWS) }\end{array}$ & \% of Total GWS & $\begin{array}{c}\text { Surface Water } \\
\text { Sources (SWS) }\end{array}$ & \% of Total SWS & $\begin{array}{c}\text { Total Supply } \\
\text { Sources TSS }\end{array}$ & \% of Total TSS \\
\hline Domestic & 183 & 79 & 49 & 21 & 231 & 29 \\
Industrial & 35.5 & 94.4 & 2.1 & 5.6 & 37.6 & 5 \\
Agriculture & 256 & 49.1 & 265 & 50.9 & 521 & 65 \\
Other & 7.3 & 64.6 & 4 & 35.4 & 11.3 & 1 \\
\hline
\end{tabular}

Table 4. Previous, current and projected water demand in MCM.

\begin{tabular}{|c|c|c|c|c|}
\hline \multirow{2}{*}{ Use } & \multicolumn{4}{|c|}{ Year } \\
\hline & 1999 & 2005 & 2010 & 2020 \\
\hline Domestic & 231 & 382 & 434 & 611 \\
\hline Industrial & 37.6 & 81 & 99 & 146 \\
\hline Agriculture & 521 & 858 & 904 & 890 \\
\hline Total & 789.6 & 1321 & 1436 & 1647 \\
\hline
\end{tabular}


Table 5. Water management and projections in MCM.

\begin{tabular}{cccc}
\hline Year & Available Water Supply & Demand & Deficit \\
199 & 801 & 789.6 & +11.4 \\
2005 & 816 & 1321 & 505 \\
2010 & & 1436 & 620 \\
2020 & & 1647 & 831 \\
\hline
\end{tabular}

1) Building Al-Wehda dam adds 100 MCM to the water supply in Jordan. The project is on hold until a peace treaty is forged between Syria and Israel.

2) The main source of additional water supply in Jordan will come from the Dead Sea-Red Sea channel project (or the Peace Conduit). This project is in its early phases. The environmental assessment study and feasibility study were just awarded to French and British companies. When completed, this project will provide Jordan with 570 MCM in 2022. The project is in co-operation between Jordan, Egypt, Israel, and Palestine with the financial support from the world community (the United States of America, the European Union, the World).

3) Back and other financial agencies. This is a major piece in the water supply puzzle for Jordan to meet its future water supply.

4) The Disi Project is operational and was completed in 2013 after two years delay, which will increase the water supply from this basin by 100 MCM. This supply sources is unsustainable (fossil basin) which is projected to be depleted in 50 years. This is a temporary fix but it's necessary.

5) More surface water can be harvested by employing better water management practices and building small earthen dams. The exploitation of additional surface water will add 139 MCM to the current 395 MCM.

6) Employing non-traditional water management practices will increase water supply. Some of these practices include but not limited to: improvement of the effluent quality form WWTP by employing new technologies and improve water retention in the WWTP stabilization ponds. These practices will add about 89 MCM in 2020 to the current level of $80 \mathrm{MCM}$.

7) Invest in desalination technology utilizing sustainable energy sources like solar and wind energies. Jordan implemented two projects that will add 65.5 MCM of available water in 2020 to the current levels of desalinated water of 31 MCM.

8) Utilizing surface runoff to recharge groundwater will add about $26 \mathrm{MCM}$ above the current recharge amount of 56 MCM.

\section{Conclusions}

Evaluation of the completed projects, proposed projects and the implementation of the strategies suggested by the Jordanian government show that it is possible that Jordan will be able to meet its water demand or close to meet it by 2020. This paper did not consider climate changes' impacts on Jordan's water resources and no adaptation strategies were considered [7]. The authors believe that unless the peace conduit is carried out, Jordan's water supply will severely suffer under climate change scenarios. Until then, it is suggested that the Jordanian Government implement one or all of the proposed these short-term fixes:

1) Improve the portable water infrastructure which will save about $30 \%-40 \%$ of the water losses (leaks and delivery efficiency).

2) Control illicit surface water use and illicit over pumping from groundwater basins.

3) Enforce existing and propose stricter laws on sewerage and industrial effluent to municipal WWTPs.

4) Reduce the agriculture water demand to a level that is appropriate with its economic impact on the county.

5) Invest in agriculture water efficiency technology and practices.

6) Invest in new water treatment technologies and sustainable water supply [2] [8].

7) Increase outreach efforts to citizens and provide incentives to water conservation efforts especially from the agricultural sector.

8) Increase the use of recycled water to add to the reliability of the water supply.

\section{References}

[1] Mohsen, M. (2008) Water Needs in the Middle East Region, from Red Sea to Dead Sea-Water and Energy. Presenta- 
tion at Sharing Knowledge across the Mediterranean (4) MAICh, Chania, 7-9 April 2008.

[2] Mohsen, M. and Al-Jayyousi, O. (1999) Brackish Water Desalination: An Alternative for Water Supply in Jordan. Desalination, 124, 163-174.

[3] Tutundjian, S. (2001) Water Resources in Jordan. World Bank, Amman. http://www.usaidjordan.org/upload/key-doc/water\%20resources\%20in\%jordan\%202001.pdf

[4] Al-Fataftah, A. and Abu-Taleb, M. (1992) Jordan's Action Plan. The Canadian Journal of Development Studies, 13, 153-171. http://dx.doi.org/10.1080/02255189.1992.9669488

[5] Raddad, K. (2005) Water Resources and Use. Workshop on Environment Statistics, Dakar, 28 February-4 March 2008.

[6] Halasah, N. and Ammary, B. (2007) Groundwater Resources in Jordan. http://www.emwis.org/WFG/GROUNDWATER\%20Resources\%20Jordan\%20\%20Nizar\%20Halasah.doc

[7] Abu-Taleb, M. (2000) Impacts of Climate Change Scenarios on Water Supply and Demand in Jordan. Water International, 25, 457-463. http://dx.doi.org/10.1080/02508060008686853

[8] Abdulla, F.A. and Al-Shareef, A.W. (2009) Roof Rainwater Harvesting System for Household Water Supply in Jordan. Desalination, 243, 195-207. 